\title{
Deep Anterior Lamellar Keratoplasty (DALK Pachy-bubble) OCT guided. Case Report
}

\section{Queratoplastia Lamelar Anterior Profunda (DALK Pachy-bubble) guiada por OCT transoperatorio. Caso clínico}

\author{
Jorge Luis Domene-Hinojosa ${ }^{1 *}$, Sarelle Ceja-Meraz ${ }^{2}$, Ana Garcia-Treviño ${ }^{3}$, Guadalupe Espinosa-Velez², \\ Diego Garcia-Pisanty², Eduardo Cornu-Melgoza ${ }^{3}$ and Jorge Domene-Hickman ${ }^{4}$
}

${ }^{1}$ Vision Maker director; ${ }^{2}$ Cornea and anterior segment, Vision Maker; ${ }^{3}$ Cornea and anterior segment fellow, IMSS UMAE 25; ${ }^{4}$ Medical Student, Instituto Tecnológico y de Estudios Superiores de Monterrey, Campus Monterrey. Monterrey, Nuevo Leon, Mexico

\begin{abstract}
Introduction: Using new technology, the microscope OPMI Lumera ${ }^{\circledR}$ and RESCANTM 700 of Zeiss company, that includes an integrated optical coherence tomography system, with which deep anterior lamellar keratoplasty with intraoperative pachymetry (DALK pachy-bubble) is optimized because of the capacity to observe on the screen the corneal depth during various steps of the surgery achieving greater security and reducing the risk of failure in the separation of Descement-stromal interface. Given the difficulty of finding the correct corneal plane, this technology is a major breakthrough in the lamellar transplants. The case and intraoperative clinical photographs in a patient diagnosed with keratoconus occurs. Case Report: Male 28 years old, diagnosed 5 years ago with keratoconus in his left eye checked by Pentacam ${ }^{\oplus}$. No history of importance or systemic pathology added. Visual acuity OD: 20/50, BCVA OD: 20/20; OI: 20/400, BCVA Ol: 20/400. The ophthalmic examination left eye presents: Munson sign, Fleischer ring and Vogt striae, without corneal opacities. The patient underwent surgery with bubble DALK pachy guided intraoperative OCT successfully. Conclusion: This is a breakthrough technology that enhances intraoperative visualization of the corneal layer, thus optimizing the surgical steps needed to achieve air separation of Descement-stromal interface by big bubble technique and intraoperative pachymetry (DALK pachy-bubble).
\end{abstract}

Key words: Deep anterior lamellar keratoplasty. Intraoperative pachymetry. Keratoconus. Tomography optical coherence. Descemet stromal interface.

\section{Resumen}

Introducción: Utilizando nueva tecnología, el microscopio OPMI Lumera ${ }^{\circledR} 700$ y RESCANTM 700 de la casa Zeiss, este microscopio incluye un sistema integrado de tomografía de coherencia óptica (OCT), con el cual se optimiza el procedimiento de queratoplastia lamelar anterior profunda con paquimetria transoperatoria (DALK pachy-bubble) al poder observar en la pantalla la profundidad corneal durante los diferentes pasos de la cirugía, logrando mayor seguridad, y disminuyendo el riesgo de fracaso en la separación de la interfase estroma-Descemet. Teniendo en cuenta la dificultad para encontrar el plano corneal correcto, esta tecnología es un avance importante en los trasplantes lamelares. Se presenta el caso y las imágenes clínicas transoperatorias de un paciente con diagnóstico de queratocono. Caso clínico: Varón de 28 años de

Correspondence:

*Jorge Luis Domene-Hinojosa

Av. Hidalgo, 2425, consultorio 800

Col. Obispado

Date of reception: 12-05-2016

Date of acceptance: 04-07-2016

DOI: 10.24875/RMOE.M18000028
Available online: 17-09-2018 Rev Mex Oftalmol (Eng).2018;92(5):232-235 www.rmo.com.mx 
edad, diagnosticado hace 5 años con queratocono del ojo izquierdo, y comprobado por Pentacam ${ }^{\oplus}$. Sin antecedentes de importancia, y sin enfermedad ocular o sistémica agregada. Agudeza visual del ojo derecho (OD): 20/50 sc, AVMC: 20/20 y ojo izquierdo (OI): 20/400 sc, AVMC: 20/80. A la exploración oftalmológica del Ol presenta: signo de Munson, anillo de Fleischer y estrías de Vogt, sin opacidades corneales. El paciente es intervenido quirúrgicamente con la técnica DALK pachy-bubble, guiada por OCT transoperatorio en forma exitosa. Conclusión: Esta tecnología es un avance importante, que mejora la visualización transoperatoria de las capas corneales, permitiendo optimizar los pasos quirúrgicos necesarios para lograr la separación aérea de la interfase estroma-Descemet mediante la técnica de gran burbuja y paquimetria transoperatoria (DALK pachy-bubble).

Palabras clave: Queratoplastia lamelar anterior profunda. Paquimetría transoperatoria. Queratocono. Tomografía de coherencia óptica. Interfase estroma Descemet.

\section{Introduction}

Using the new technology OPMI Lumera ${ }^{\circledR} 700$ and RESCANTM 700 from Zeiss, this microscope includes an optical coherence tomography (OCT) integrated system, which optimizes the procedure of deep anterior lamellar keratoplasty with intraoperative pachymetry (DALK pachy-bubble). This allows the observation of high-resolution images by OCT, like corneal microstructure, including the Descemet membrane, during the different steps of the surgery, achieving greater safety, and decreasing the risk of failure when separating the Descement-stromal interface. Considering the difficulty in finding the correct corneal plane, this technology is an important advance in lamellar transplants. We present a case with intraoperative clinical images of a patient with a diagnosis of keratoconus.

\section{Clinical case}

A 28-year-old male, diagnosed 5 years ago with keratoconus in the left eye (OS) by Pentacam ${ }^{\circledR}$, with a central thickness of $378 \mu \mathrm{m}$ (366 ccc at its thinnest point), corneal apex with lower nasal displacement, mean keratometry $(\mathrm{Km}) 58.6 \mathrm{D}, \mathrm{I} / \mathrm{S}: 2.8$ with high KISA index, and grade 3-4 keratoconus (Figs. 1 y 2). No relevant history and without additional ocular or systemic disease. Visual acuity of the right eye (OD): 20/50 w/o correction, BCVA 20/20 and OS 20/400 w/o correction, BCVA 20/80. Biomicroscopic examination of the OS showed Munson sign, Fleischer ring and Vogt lines, without the presence of corneal opacities. The rest of the anterior segment without alterations. The patient successfully underwent DALK pachy-bubble technique, guided by intraoperative OCT. The key points during surgery with this technology are easier visualization, such as the partial trephination of the corneal stroma, the placement of intrastromal air with Descemet visualization separated from the corneal stroma (Fig. 1), creating a Descement-stromal interface. Other key point is a corneal incision using a knife up to the Descement-stromal interface, visualizing the retraction of Descemet membrane to the stroma (Fig. 2); at this point, it is necessary to remove the knife to avoid inadvertent perforations. The images of the Descemet membrane with a quadrant of residual stroma are also shown (Fig. 3A). Then, the donated corneal button is placed (with Descemet membrane stripping, (Fig. 3B) and sutured with simple 10-0 nylon sutures, without complications.

\section{Discussion}

Since its inception in the 1950s, José Barraquer and colleagues in Colombia dissected 2 thirds of the corneal stroma, both in the donor and in the recipient ${ }^{1}, \bar{a}$ technique that did not obtain great popularity due to the poor final visual acuity due to surface irregularities and interface scarring. Since 1984, when Eduardo Arenas Archila coined the term "deep anterior lamellar keratoplasty" using intrastromal air for tissue separation", anterior lamellar transplants have had a sustained development, evolving into techniques that can achieve the separation of the Descement-stromal interface in a safe way. This techniques aim to preserve the Descemet membrane and avoid stromal remnants, since it has been proven that this step is essential to achieve high-quality visual results.

Over time it has been shown that deep anterior lamellar transplants have great advantages compared to penetrating keratoplasty, because intraoperative risk is reduced by avoiding complete corneal trephination, the endothelium of the recipient is preserved and thus a greater 


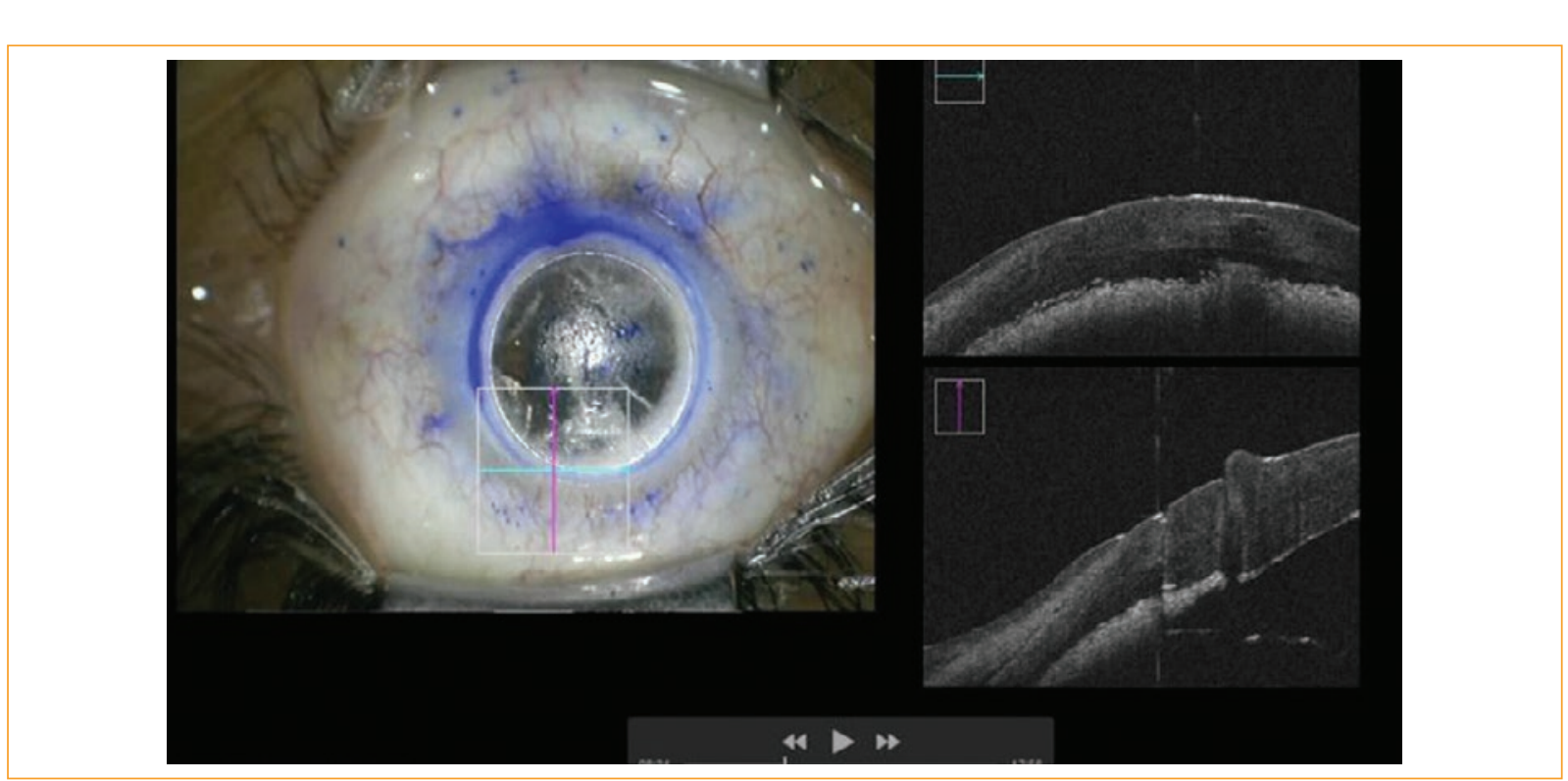

Figure 1. Intrastromal air placement with Descemet visualization separated from the corneal stroma (blue arrow), creating a Descemet-stroma interface.

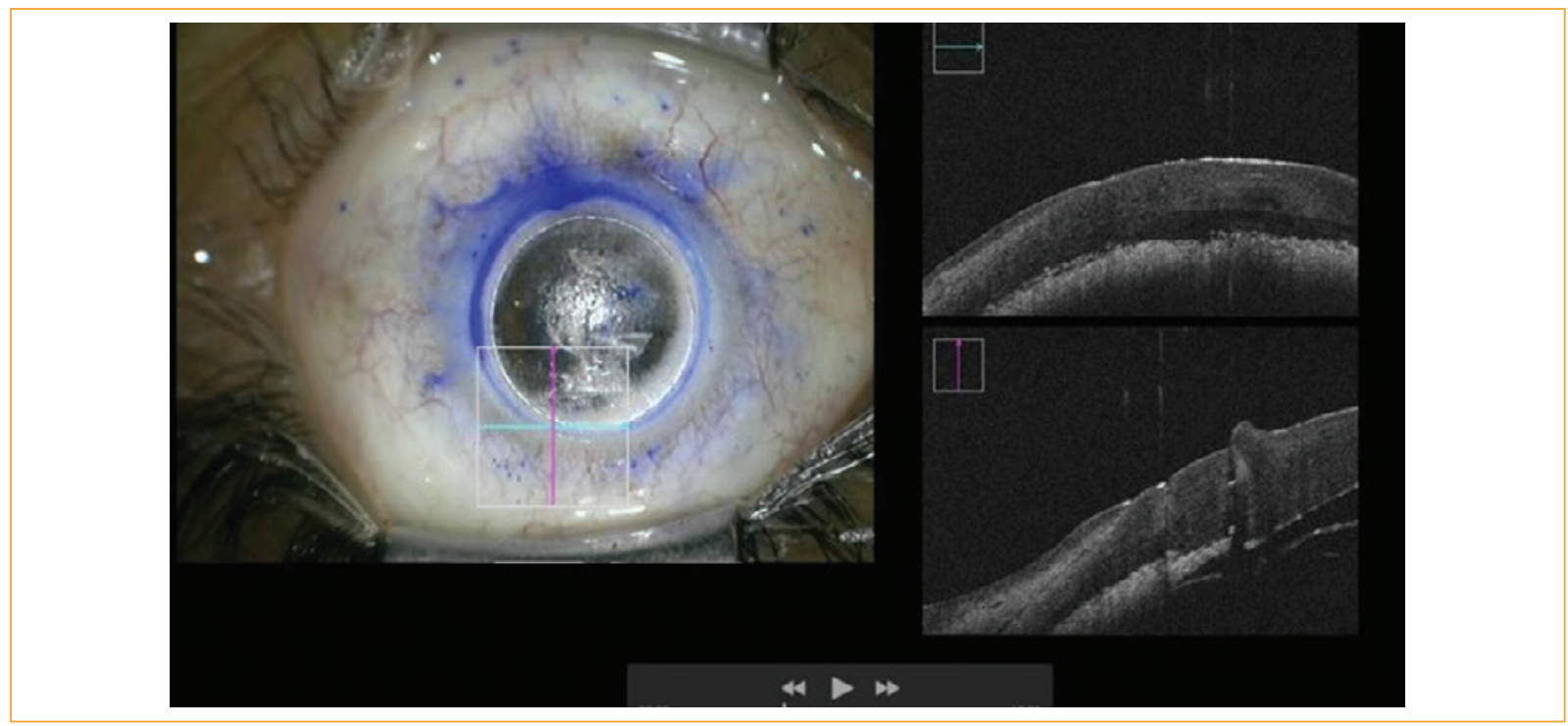

Figure 2. Corneal incision using knife to Descemet-stroma interface, with visualization of Descemet membrane retraction towards the stroma.

number of cells ${ }^{3}$, and it prevents immunological rejection $^{3,4}$. Other advantages are greater resistance to trauma, decreased use of intraoperative steroids, lower risk of complications such as synechia, cataract, intraocular infections, glaucoma ${ }^{2,5}$ and expulsive hemorrhage, to name a few. However, in many countries including Mexico this technique has not become popular due to the technical difficulty and its steep learning curve. Currently, the risk of perforation is from 10 to $30 \%$ in expert hands ${ }^{4}$.

\section{Conclusion}

The use of the new technology OPMI Lumera ${ }^{\circledR} 700$ and RESCANTM 700 optimizes the identification of the corneal layers by providing OCT cross sections. This can directly influence the risk of Descemet membrane perforation by providing direct visualization in critical steps such as partial corneal trephination, incision with diamond knife, deep air lamellar dissection and deep stromal cut towards the air interface. 


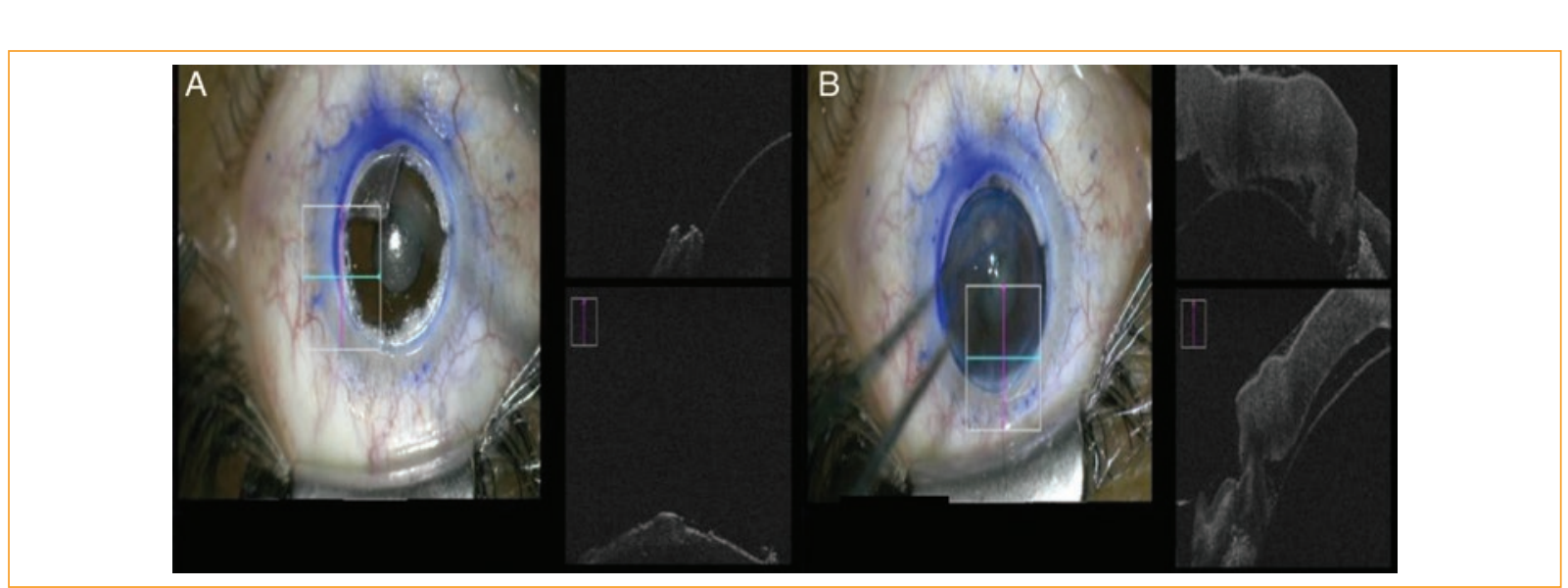

Figure 3. A: Descemet membrane during dissection. B: Placement of a donated corneal button, after Descemet membrane stripping.

\section{Ethical disclosures}

Protection of human and animal subjects. The authors declare that no experiments were performed on humans or animals for this study.

Confidentiality of data. The authors declare that they have followed the protocols of their work center on the publication of patient data.

Right to privacy and informed consent. The authors declare that no patient data appear in this article.

\section{Funding}

The author(s) received no specific funding for this work.

\section{Conflicts of interest}

The authors declare no conflicts of interest.

\section{References}

1. Anwar M, Teichmann K. Deep lamellar keratoplasty: Surgi-cal techniques for anterior lamellar keratoplasty with andwithout baring of Descemet's membrane. Cornea. 2002;21:374-83.

2. Shimmura S, Tsubota K. Deep anterior lamellar keratoplasty.Current Opinion in Ophthalmology. 2006;17:349-55.

3. Sogutlu Sari E, Kubaloglu A, Unal M, Pinero D, Bulut N, Erol MK, et al. Deep anterior lamellar keratoplasty versus penetratingkeratoplasty for macular corneal dystrophy: a randomized trial. Am J Ophthalmol. 2013;156:267-74.

4. Trimarchi F, Poppi E, Klersy C, Piacentini C. Deep lamellar kera-toplasty. Ophthalmologica. 2001;215:389-93.

5. Tao YK, LaBarbera M, Ehlers JP, Srivastava SK, Dupps WJ. Image-guided modified deep anterior lamellar keratoplasty (DALK)corneal transplant using intraoperative optical coherence tomo-graphy. Invest Ophthalmol Vis Sci. 2015;56:1966. 